\author{
PRASHANT KUMAR RAI ${ }^{1}$, \\ GIRJESH KUMAR ${ }^{2}$, AVINASH TRIPATHI ${ }^{3}$ \\ ${ }^{1,2}$ Assistant Professor, Department of Genetics and Plant Breeding (Seed \\ Science and Technology), Sam Higginbottom Institute of Agriculture, \\ Technology and Sciences, Naini, Allahabad-211007, Up, India \\ ${ }^{3}$ H.N.B. Government Post Graduate College, Allahabad-211008, India \\ E-mail: prashant.rai81@gmail.com
}

\section{INDUCED CYTOMICTIC DIVERSITY IN MAIZE (ZEA MAYS L.) INBRED}

Introduction. Mutation breeding has been used for improving oligogenic and polygenic characters, disease resistance and quantitative characters including yielding ability. Mutagenesis may induce desirable mutant alleles, which may not be previously present in the germplasm. Mutation breeding relieves the complete dependence of breeders on the natural germplasm, but it should be remembered that mutation breeding could not minimize the necessity of germplasm collections; it only serves as a useful supplement to the available germplasm [1,2].

Meiosis is highly coherent and genetically programmed process and comprises pairing of homologous chromosomes, crossing over, and the reduction in chromosome number, the requirement of two cell divisions and the lack of S period between the two divisions [3]. Like any other biological process, all the sequential steps involved in meiosis are controlled by a large array of genes [4,5]. Mutation in any of these genes that govern micro or mega sporogenesis from pre meiotic to post meiotic events can lead to serious anomalies in the whole process resulting in the genetically aberrant end products having adverse impact on fertility and overall reproductive efficiency of the species.

The phenomenon of cytomixis is characterized by the migration of chromatin/chromosomes between the proximate meiocytes through cytoplasmic channels or intercellular bridges. Though an infrequent cytological phenomenon, it has been reported to occur in large array of plants $[6,7]$. Pollen mother cells (PMCs) deriving from the process of cytomixis can have a variable chromosome number as a consequence of the manner in which the process takes place. Meiocytes may be involved in one or more cytomictic events, and the migration of the nuclear content may involve all the chromosomes or part of the chromosomes of the donor cell. As it can be expected that a greater part of the gametes deriving from such PMCs will be aneuploid or polyploid, some authors have considered cytomixis as a mechanism of evolutionary importance for plants $[8,9]$. For others, it represents just an unfavourable phenomenon with deleterious effects on fertility [10]. Until now cytomixis has been investigated in numerous species [1113 ] including some grass species [14].

The present investigation describes the meiotic study of gamma irradiated diploid plants of Zea mays L. $(n=20)$ inbred showing high degree of cytomixis during microsporogenesis. The purpose of this study is to elucidate whether the passage of

C) PRASHANT KUMAR RAI, GIRJESH KUMAR, AVINASH TRIPATHI, 2010 


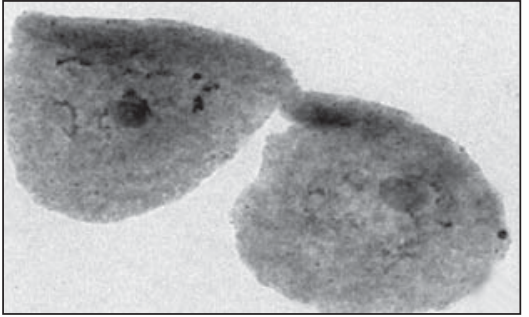

Fig. 1. Cytoplasmic channel between two PMCs at prophase I

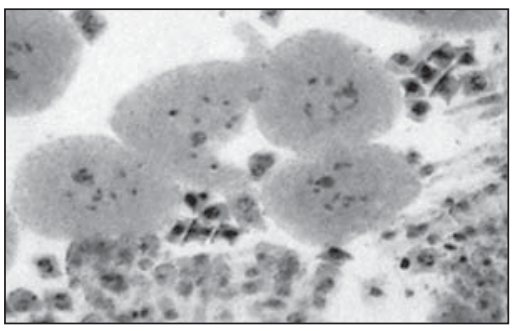

Fig. 4. Chromatin transfer between two PMCs at metaphase I

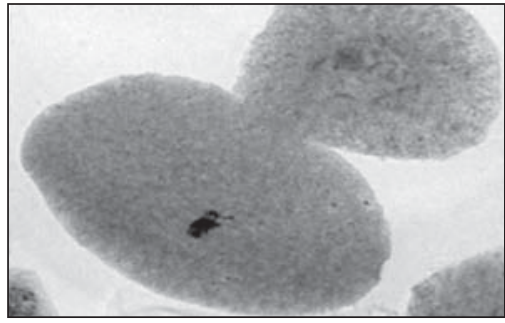

Fig. 2. Cytomixis between dissimilar stages (Prophase and Metaphase I)

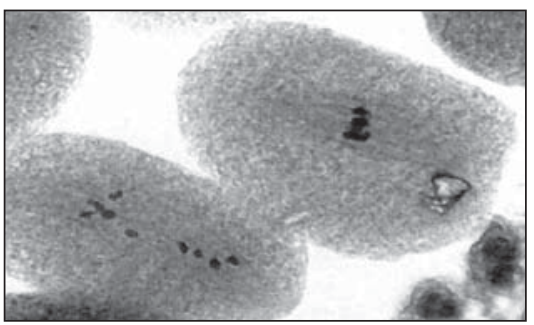

Fig. 5. Partial migration between two PMCs

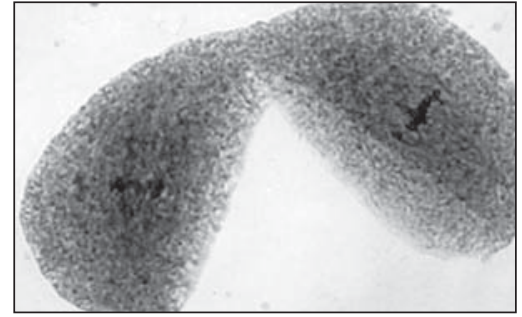

Fig. 3. Cytomixis between similar stages (Metaphase I)

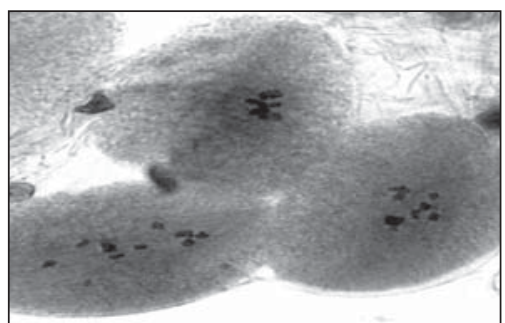

Fig. 6. Partial migration between three PMCs

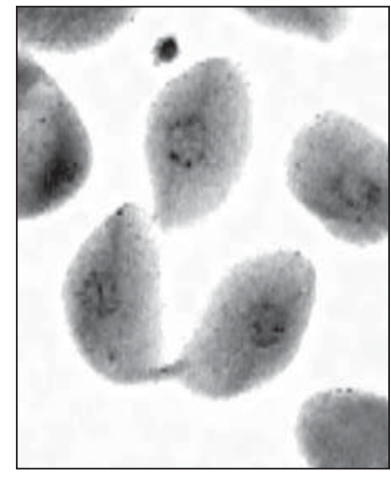

Fig. 7. Beak formation between two PMCs $(40 \times)$

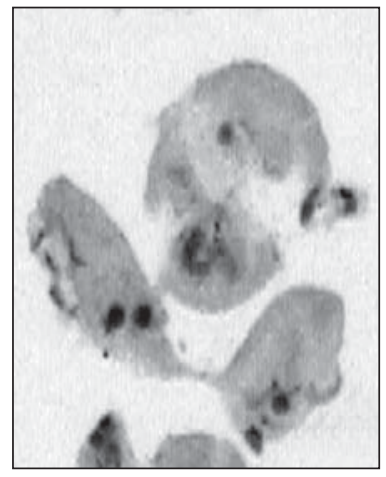

Fig. 8. Beak formation between two PMCs $(40 \times)$

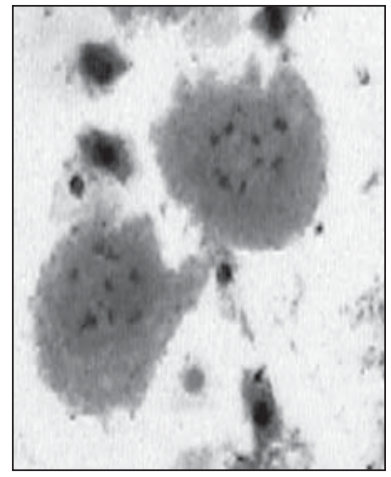

Fig. 9. Beak formation between two PMCs $(40 \times)$

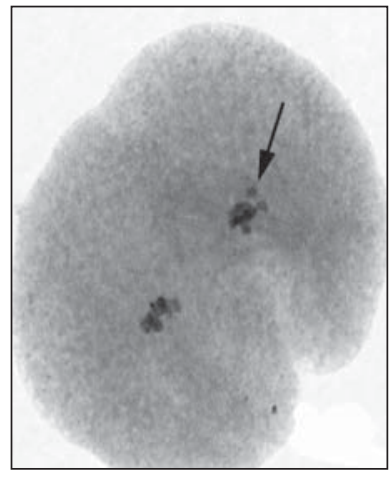

Fig. 10. Cytomixis between two PMCs with Precocious movement

nuclear material between meiocytes constitutes an effective mechanism for the formation of $2 n$ pollen or if it is only an abnormal phenomenon, which leads to meiocytes with altered chromosomal content and does not generate significant modifications of the chromosome number.

Materials and methods. Seeds of inbred lines of Zea mays L. viz. CM-135, CM-136, CM-137, CM-138, CM-142 and CM-213 were obtained from Division of Genetics, Indian Agricultural Research Institute (I.A.R.I.), New Delhi, India.

Dry (10 to $12 \%$ moisture content) and healthy seeds of these inbred lines were irradiated at three doses of gamma irradiation viz. 200, 400 and 600 Gy from National Botanical Research Institute (N.B.R.I.), Lucknow, India. The treated seeds were sown along with controls in replicates.

For meiotic studies, three replicates were maintained for each dose of treatment simultaneously, suitable control sets were maintained in distilled water and then they were sown under natural conditions to raise $\mathrm{M}_{1}$ generation. At the time of 
flowering, young flower buds from 15 to 20 randomly selected plants from each treatment dose as well as control were fixed in freshly prepared solution of 1:3 acetic acid : absolute alcohols for 24 hours and preserved in $70 \%$ alcohol at $4{ }^{\circ} \mathrm{C}$. Slides were prepared using anther squash technique with $2 \%$ acetocarmine. More than 500 dividing PMCs from each treated plant, as well as control populations, were studied and analysed. Pollen grains were also stained with $2 \%$ acetocarmine to study pollen fertility. Photographs were taken from freshly prepared slides using a Nikon research photomicroscope.

Results. The experimental results presented in table, revealed that four plants from 200 Gy treatment were showing cytomictic connections between two or more PMCs. Cytomixis was altogether absent in the control plants. It was also interesting to note that out of the six inbred lines of Zea mays L. only inbred CM-138 displayed cytoplasmic connections (Fig. 1 to 8). Two types of connections between PMCs were observed, viz. Cytoplasmic channels and direct fusion. Cytomixis through cytoplasmic channels was frequent among PMCs (Fig. 1, 7, 8 and 9). The direct fusion of PMCs was observed at various stages of cell division (Fig. 2, 3 and 10) and the frequency of cells showing cytomixis through this method was greater during the first part of meiotic division (Table). Partial or total migration of chromosomes (Fig. 5 and 6) or chromatin material in one or several directions to the neighbouring cells was also noticed resulting into increased or decreased chromosome number in PMCs. Cytoplasmic connections connecting two or three or more PMCs were also commonly observed with no evident chromosome transfer. Cytomictic connections between more than two PMCs were also encountered but in very low frequency (Fig. 7 and 8). Some PMCs were found to have a cytoplasmic channel with one PMC and direct fusion with another. In most instances the cytomixis was observed between the PMCs in same division stages, but it was also noticed between PMCs of different stages (Fig. 2). Cytomixis through both of the methods was more frequent at various stages of meiosis I as compared to meiosis II (Table). Some other chromosomal abnormalities like stickiness, laggards, chromatin bridges, fragments etc, were also observed in the cytomictic plants (Table). Along with normal tetrads, five, six or more daughter nuclei were also visible at telophase II resulting in polyads in affected plants.

Discussion. Cytomixis and spontaneous fusion of pollen mother cells have been reported in number of angiosperm species [15-17]. The phenomenon of cytomixis was firstly described by Koernicke [18] in PMCs of Crocus vernus and by Miehe [19] in the epidermal layers of various monocotyledons plants. It has also been observed in Pilocarpus pennatifolium [20], Plantago [11], Cicer [12], Centella asiatica [21], Brassica napus and Brassica campestris [22], Zea mays [23], Glycine max [16], Gossypium hirsutum [2], Medicago sativa [7]. Pollen grains

Effect of Gamma Irradiation at 200 Gy Dose of four plants of inbred line CM-138

\begin{tabular}{|c|c|c|c|c|c|c|c|c|c|c|c|c|c|c|}
\hline \multirow{3}{*}{ Plants } & \multirow{3}{*}{ 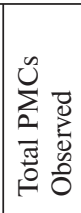 } & \multirow{3}{*}{ 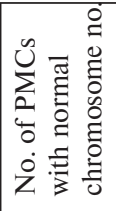 } & \multirow{3}{*}{ 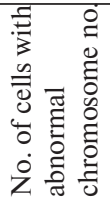 } & \multirow{3}{*}{ 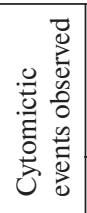 } & \multirow{2}{*}{\multicolumn{2}{|c|}{$\begin{array}{c}\text { Types of cytomixis } \\
\text { (Mean) }\end{array}$}} & \multicolumn{6}{|c|}{$\begin{array}{l}\text { Cells showing cytomixis } \\
\text { at various stages of meiosis (\%) }\end{array}$} & \multirow{3}{*}{ 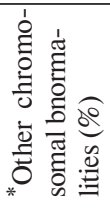 } & \multirow{3}{*}{ 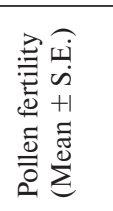 } \\
\hline & & & & & & & \multicolumn{3}{|c|}{ Meiosis I } & \multicolumn{3}{|c|}{ Meiosis II } & & \\
\hline & & & & & $\mathrm{CC}$ & DF & $\mathrm{P}$ & MI & AI & TI & MII & AII & & \\
\hline Control & 564 & 564 & - & - & - & - & - & - & - & - & - & - & - & $\begin{array}{l}97.36 \pm \\
\pm 0.42^{*}\end{array}$ \\
\hline 1 & 540 & 508 & 32 & 49 & 28 & 21 & 2.40 & 1.29 & 1.66 & 1.11 & 1.48 & 0.74 & 8.14 & 64.73 \\
\hline 2 & 555 & 536 & 19 & 35 & 21 & 14 & - & 1.98 & 0.90 & 2.16 & - & 1.44 & 8.46 & 70.45 \\
\hline 3 & 571 & 514 & 57 & 62 & 33 & 29 & 1.57 & 2.28 & 1.93 & 1.23 & 1.09 & 1.75 & 11.03 & 54.22 \\
\hline 4 & 536 & 513 & 23 & 23 & 16 & 7 & 1.40 & 0.55 & 0.27 & - & 1.17 & - & 6.71 & 59.28 \\
\hline
\end{tabular}

Abbreviations: PMCs - Pollen mother cells, No. - Number, CC - Cytoplasmic channel, DF - Direct Fusion, P Prophase, MI - Metaphase I, AI - Anaphase I, TI - Telophase I, MII - Metaphase II, AII - Anaphase II, TII Telophase II, * Other chromosomal abnormalities - Diakinesis, Univalents, Fragmentation, Laggards etc. 
derived after the process of cytomixis can have a variable chromosome number as a consequence of the manner in which the process takes place. Meiocytes may be involved in one or more cytomictic events and the migration of the nuclear content may involve all the chromosomes or part of the chromosome of the donor cell. It can be expected that microspores produced from such pollen mother cells will be aneuploid or polyploid.

Some authors have considered cytomixis as a mechanism of evolutionary importance for plants $[8,9]$. Investigation in Zea mays L. confirms that the migration of chromosomes is a real event that cannot be misunderstood as an artifact produced by fixation or mechanical injuries.

During the present investigation a number of cases of chromosome transfer were observed at 200 Gy dose of gamma irradiation in inbred line CM138. Although cytomixis has been reported in several plant species, its origin is not clear. Among the factors proposed to cause cytomixis are: 1 . The influence of genes [24], 2. Abnormal formation of the cell wall during premeiotic divisions [25], 3. Action of chemical agents [11-13], 4. Changes in the biochemical process that involves microsporogenesis modifying the microenvironment of affected anthers [14], 5. The effect of gamma irradiation resulting in an imbalanced and sterile genetic system $[2,26], 6$. The presence of male sterile gene and its frequency altered by environmental factors [27], environmental stress and pollution [7, 16, 28], 7. Crop culture conditions [29], 8. Pathological conditions [30], 9. Temperature anomalies [31], 10. Effect of fixation [32], 11. Mechanical injury [33], 12. Genetically controlled behaviour [34].

Kamra [25] working on PMCs of Hordeum believed that no amount of defecting squashing or application of pressure could produce such small protrusions so close to another, or to form PMCs with extra fragments or increase the number of bivalents in them specially at metaphase. During present investigation, the comparative analysis of control and treated sets regarding cytomixis clearly indicates that the cause of cytomixis might be abnormal genetic behaviour due to treatment with gamma rays. This study revealed that all the stages of meiosis were equally susceptible to cytomixis, contrary to the general belief that early stages are more favourable [34]. It has also been found that cytomixis was responsible for the sterility because of the fact that, firstly, the number of pollens would be considerably reduced due to degeneration of cells with no or very little genetic material and secondly, most of the cells completing all the meiotic stages, would be genetically imbalanced because of less or more number than the normal ones.

In the inbred line, CM-138 at 200 Gy dose of gamma rays, a very peculiar abnormality was detected. Four plants from this treatment set were found to be engaged in a rare phenomenon reported as «Cytomixis» in many references. In these plants, characteristic cytoplasmic connections were frequent during all stages of meiosis. Although cytoplasmic connections were frequent but true chromosome transfer was rarely observed among the PMCs. However, the detection of PMCs with additional chromosomes or PMCs with reduced number of chromosome provided an evidence of chromosomal transfer through cytomixis.

Conclusively, the present investigation clearly elucidates that in the inbred CM-138 of Zea mays L., induced cytomixis through gamma ray treatment may be considered to be a possible source of production of aneuploid and polyploid gametes. Such aneuploid and polyploid gametes can be used in maize breeding programmes to create genetic variability through altered chromosome numbers. Thus, this phenomenon may have potential applications in Zea mays L. improvement in the sense of diversity and ever yield potential.

Authors are thankful to Division of Genetics, Indian Agricultural Research Institute (I.A.R.I.), NewDelhi, India for providing inbred seeds of maize and National Botanical Research Institute (N.B.R.I.), Lucknow, UP, India for providing gamma irradiation facility. Sincere thanks to all the members of Plant Genetics Laboratory for their encouragement and support.

\section{Prashant Kumar Rai, Girjesh Kumar, Avinash Tripathi ИНДУЦИРОВАННОЕ ЦИТОМИКТИЧЕСКОЕ РАЗНООБРАЗИЕ У ИНБРЕДНОЙ КУКУРУЗЫ (ZEA MAYS L.)}

Мутационная селекция используется для улучшения моногенных и полигенных признаков, устойчивости к заболеваниям и количественных характеристик, включая урожайность. Цитологическая стабильность инбредных линий кукурузы важна с точки зрения их широкого использования в генетике и селекции. Исследования, проведенные на кукурузе, подтверждают, что 
миграция хромосом является реальным событием, которое не может быть неправильно понято как артефакт, полученный в результате фиксации или механических повреждений. В этом исследовании мы обнаружили, что в шести инбредных линиях кукурузы СМ-135, СМ-136, СМ-137, СМ-138, СМ-142 и СМ-213 при гамма-облучении в разных дозах (200, 400 и $600 \mathrm{~Gy})$ некоторые из растений инбредной линии СМ-138 при дозе $200 \mathrm{~Gy}$ проявляли характерные цитоплазматические связки на всех стадиях мейоза. Четыре растения из этой серии опытов демонстрировали редкое явление, известное как цитомиксис. Это показывает, что инбредная кукуруза с индуцированным гамма-лучами цитомиксисом может рассматриваться как возможный источник получения анеуплоидных и полиплоидных гамет. Это явление может использоваться для увеличения разнообразия кукурузы и улучшения урожайности.

\section{Prashant Kumar Rai, Girjesh Kumar, Avinash Tripathi ІНДУКОВАНА ЦИТОМІКТИЧНА РІЗНОМАНІТНІСТЬ В ІНБРЕДНОЇ КУКУРУДЗИ (ZEA MAYS L.)}

Мутаційна селекція використовується для поліпшення моногенних та полігенних ознак, стійкості до захворювань і кількісних характеристик, включаючи врожайність. Цитогенетична стабільність інбредних ліній кукурудзи важлива з точки зору їх широкого використання в генетиці та селекції. Дослідження, проведені на кукурудзі, підтверджують, що міграція хромосом $€$ реальною подією, котра не може бути неправильно зрозумілою як артефакт, який отримали в результаті фіксації чи механічних пошкоджень. В цьому дослідженні ми виявили, що в шести інбредних лініях кукурудзи СМ-135, СМ-136, СM-137, СМ-138, СМ-142 i СМ-213 при гамма-опроміненні різними дозами (200, 400, 600 Gy) деякі з рослин інбредної лінії СМ-138 при дозі $200 \mathrm{~Gy}$ проявляли характерні цитоплазматичні зв'язки на всіх стадіях мейозу. Чотири рослини з цієї серії дослідів демонстрували рідкісне явище, відоме як цитоміксис. Це показує, що інбредна кукурудза з індукованим гамма-променями цитоміксисом може розглядатися як можливе джерело отримання анеуплоїдних та поліплоїдних гамет. Це явище може використовуватися для збільшення різномаїття кукурудзи та поліпшення врожайності.

\section{REFERENCES}

1. Singh B.D. Plant Breeding, Principle and Methods, Forth Edition, New Delhi, Kalyani Publishers, 1990.

2. Sheidai M., Azarani H., Hosseininejad Z. Cytogenetic study of gamma irradiated lines of Cotton (Gossypium Hirsutum L.) // J. Sciences, Islamic Republic of Iran, 2002, 13(4):311-322.
3. Latoo S.K., Khan S. Bamotra, Dhar A.K. Cytomixis impairs meiosis and influences reproductive success in Chlorophytum comosum (Thumb) Jacq.- an additional strategy and possible implications // J. Biosci, 2006, 31 (5): 629-637.

4. Falistocco E., Lorenzetti S., Falcinelli M. Microsporogenesis in desynaptic mutant of Dactylis // Cytologia, 1994, 59:309-316.

5. Sheidai M., Vafai-Tabar M., Mirzai-Nedoshan H., Hosseini-Nejad Z. Cytogenetical studies in Gossypium hirsutum L. cultivars and their hybrids // Cytologia, 1998, 63:41-48.

6. Bedi Y.S. Cytology in woody species // Proc. Indian Acad. Sci. (Plant Sci.), 1990, 100:233-238.

7. Bellucci M., Roscini C., Mariani A. Cytomixis in pollen mother cells of Medicago sativa L. // J. Hered. 2003, 94:512-516.

8. Srivastava P.K., Raina S.N. Cytomixis in Clitona temantea L. var. Pleniflora Fantz. F. pleniflora // Curr. Sci. 1980, 49:824-835.

9. Zheng G.C., Yang $Q$., Zheng $Y$. The relationship between cytomixis, chromosome mutation and karyotype evolution in Lily // Caryologia, 1987, 40:243-259.

10. Marechal R. Quelques observations sur le phenomene de cytomixie chez. Gossypium // Bull. Inst. Agron. Gembloux, 1963, 31:223-240.

11. Kumar G., Srivastava U. Cytomictic variation in Isabgol (Plantago ovata forsk) // Nucleus, 2001, 44:180-182.

12. Kumar G., Sharma $V$. Induced cytomixis in Chickpea (Cicer arietinum L.) // Nucleus, 2002, 45:24-26.

13. Bhatt Tariq Ahmad, Sahba Parveen, Ainul Haq Khan. MMS-induced cytomixis in pollen mother cells of Broad Bean (Vicia faba L.) // Turk. J. Bot., 2006, 30:273-279.

14. Koul K.K. Cytomixis in pollen mother cells of Alopecurus arundinaceus Poir. // Cytologia, 1990, 55:169-173.

15. Dagne $K$. Meiosis in interspecific hybrids and genomic interrelationships in Guizotia Cass (Compositae) // Hereditas, 1994, 121:119-129.

16. Bione N.C.P., Pagliarini M.S., De Toledo J.F.F. Meiotic behaviour of several Brasilian soybean varieties // Genet. Mol. Biol., 2000, 23(3):623-631.

17. Ghanima A.M., Talaat A.A. Cytomixis and its possible evolutionary role in Kuwait population of Diplotaxis Harra (Boraginaceae) // Bot. J. Linn. Soc., 2003, 143:168-175.

18. Koernicke $M$. Uber ortsveranderung von Zellkarnern SB Niederhein. Ges. Natur-U Heilkunde Bonn A. 1901, p. 14-25.

19. Miehe $H$. Uberdie Wanderung des Pflanzlichen Zellkernes Flora. 1901, 88:105-142.

20. Pagliarini M.S., Pereira M.A.S. Meiotic studies in Pilocarpus pennatifolius Lem. (Rutaceae) // Cytologia, 1992, 57:231-235.

21. Consolaro M.E.L., Pagliarini M.S. Cytomixis in pollen 
mother cells of Centella asiatica (L.) Urban. // Nucleus, 1995, 38:80-85.

22. Souza A.M., Pagliarini M.S. Cytomixis in Brassica napus var. Oleifera and Brassica campestris var. Oleifera (Brassicaceae) // Cytologia, 1997, 62:25-29.

23. Caetano-Pereira C.M., Pagliarini M.S. Cytomixis in maize microsporocytes // Cytologia, 1997, 62:351355.

24. Kaul M.L.H., Nirmala C. Male sterile gene action diversity in barley and pea // Nucleus, 1991, 34:32-39.

25. Kamra O.P. Chromatin extrusion and cytomixis in pollen mother cells of Hordeum // Hereditas (Lund), 1960, 46:592-600.

26. Amma C.K.S., Namboodiri A.N., Panikkar A.O.N., Sethuraj M.R. Radiation induced male sterility in Hevea brasiliensis (Wild ex Adr. De Juss) Muell. // Agr. Cytologia, 1990, 55:547-551.

27. Nirmala C., Kaul M. Male sterility in Pea. IV. // Cytologia, 1994, 59:195-201.

28. Haroun S.A., Al Shehri A.M., Al Wadie H.M. Cytomixis in the microsporogenesis of Vicia faba L. (Fabaceae) // Cytologia, 2004, 69:7-11.

29. Pierozzi N.I., Benatti R.Jr. Cytological analysis in the microsporogenesis of ramie, Boehmeira nivea Gaud (Urticaceae) and the effect of colchicines on the chiasma frequency // Cytologia, 1998, 63:213-221.

30. Boback M., Herich R. Cytomixis as a manifestation of pathological changes after the application of trifluraline // Nucleus, 1978, 20:22-28.

31. Basavaiah D., Murthy T.C.S. Cytomixis in pollen mother cells of Urochloa panicoides P. Beauv. (Poaceae) // Cytologia, 1987, 52:69-74.

32. Gottshalk $W$. Cromosome and nuclear migration during microsporogenesis of Pisum sativum // Nucleus, 1970, 13:1-9.

33. Sarvella $P$. Cytomixis and the loss of chromosome in meiotic and somatic cells of Gossypium // Cytologia, 1958, 23:14-24.

34. De Mantu, Sharma A.K. Cytomixis in pollen mother cells of an apomictic ornamental Ervatamia divericata (Linn) Alston // Cytologia, 1983, 48:201-207.

35. Maheshwari P. An introduction to the Embryology of Angiosperms. McGraw-Hill Book Co. Inc., New York, 1950.

Received 09.09.09 